EGG--2153

DE82 013505

EGG-2153

\title{
COMPARISON OF TWO OPTIONS FOR SUPPLYING GEOTHERMAL ENERGY TO THE VETERANS ADMINISTRATION MEDICAL CENTER AT MARLIN, TEXAS
}

T. F. Green

Principal Investigator

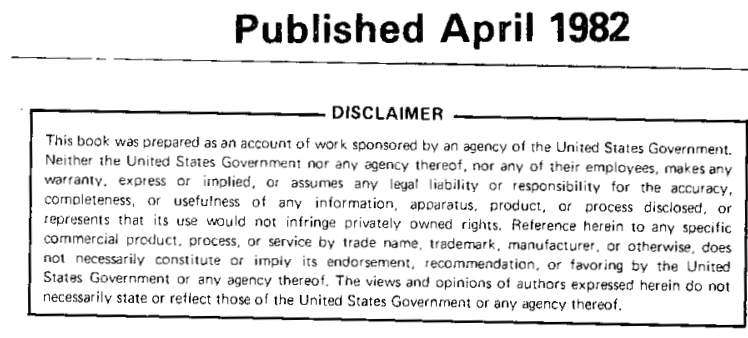

\section{Radian Corporation \\ Austin, Texas}

\begin{abstract}
NOTICE
PORTIONS OF THIS REPORT ARE ILLEGIBLE. It has been reproduced from the best available copy to permit the broadest possible availability.
\end{abstract}

Prepared for EG\&G Idaho, Inc.

Under Subcontract No. K-7920

and the U.S. Department of Energy

Idaho Operations Office

Under DOE Contract No. DE-AC07-761D01570 


\section{DISCLAIMER}

This report was prepared as an account of work sponsored by an agency of the United States Government. Neither the United States Government nor any agency Thereof, nor any of their employees, makes any warranty, express or implied, or assumes any legal liability or responsibility for the accuracy, completeness, or usefulness of any information, apparatus, product, or process disclosed, or represents that its use would not infringe privately owned rights. Reference herein to any specific commercial product, process, or service by trade name, trademark, manufacturer, or otherwise does not necessarily constitute or imply its endorsement, recommendation, or favoring by the United States Government or any agency thereof. The views and opinions of authors expressed herein do not necessarily state or reflect those of the United States Government or any agency thereof. 


\section{DISCLAIMER}

Portions of this document may be illegible in electronic image products. Images are produced from the best available original document. 


\section{FOREWORD}

The Geothermal Technical Assistance Program was developed under the premise that the majority of groups or individuals with available geothermal resources do not have the experience or manpower necessary to do a preliminary engineering and economic feasibility evaluation for geothermal energy projects. In order to disseminate technical information and to facilitate expanded use of geothermal energy resources, assistance was provided through FY-1981 in a consulting format on a first-come, staff-andfunds-available basis. Technical assistance can relate to conceptualization; engineering; economics; water chemistry implications for environmental, disposal, and material selection considerations; and planning and development strategies. This report is one of a series adapted from consultation provided to requesters either through in-house efforts or through limited efforts subcontracted to local engineering firms. The Geothermal Technical Assistance (GTA) Reports in this series, which are listed below, will be available for purchase early in 1982 by those with interest in specific geothermal applications from the U.S. National Technical Information Service:

U.S. Department of Commerce,

National Technical Information Service, 5285 Port Royal Road, Springfield, VA 22161,

(703) $557-4650$

GTA

Report Number

1.

2.

3.

4.

5.

6.

7.

8.

9.
EGG-GTH-5617

EG\&G

Report Number

*EGG-GTH-5512

*EGG-GTH-5521

*EGG-GTH-5573

*EGG-GTH-5574

*EGG-GTH-5575

*EGG-GTH-5599

*EGG-2137

*EGG-2138
Title

Aquaculture Facility Potential at Boulder Hot Springs, Boulder, Montana

Preliminary Geothermal Disposal Considerations, State Health Laboratory, Boise, Idaho

Geothermal Conversion at Veterans Hospital, Boise, Idaho

Geothermal Applications for Highway Rest Areas

Geothermal Applications for a Tannery

Preliminary Conceptual Design for Geothermal Space Heating Conversion of School District 50 Joint Facilities at Pagosa Springs, Colorado

Selected Geothermal Technical Assistance Efforts (comprising short descriptions of ten space heating projects, five district heating projects, and three heat exchanger projects)

Geothermal Source Potential and Utilization for Methane Generation and Alcohol Production (subcontractor report)

Geothermal Source Potential and Utilization for Alcohol Production (subcontractor report) 
GTA

Report Number

10.

EGG-2139

11.

*EGG-2144

12.

*EGG-2145

13.

*EGG-2146

14.

*EGG-2147

15.

*EGG-2148

16.

EGG-2149

17.

18.

19.

20.

21.

22.

23.

24.

25.
EGG-2154

EGG-2155

*EGG-2156

EGG-2152

EGG-2153

*EGG-GTH-5739

*EGG-GTH-5740
Title

Potential Geothermal Energy Applications for Idaho Elks Rehabilitation Hospital (subcontractor report)

Technical Assistance Report on a Geothermal Heating Utility for Lemmon, South Dakota (subcontractor report)

Economic Analysis for Utilization of Geothermal Energy by North Dakota Concrete Products Company (subcontractor report)

Geothermal Feasibility Analysis II for Polo School District No. 29-2, South Dakota (subcontractor report)

Preliminary Feasibility Study of Heating and Cooling Alternatives for Nebraska Western College, Scottsbluff, Nebraska (subcontractor report)

Inventory of Thermal Springs and Wells Within a OneMile Radius of Yucca Lodge, Truth or Consequences, New Mexico (subcontractor report)

Utilization of Geothermal Energy, Feasibility Study-Ojo Caliente Mineral Springs Company, Ojo Caliente, New Mexico (subcontractor report)

Geothermal Heated Office Building at Glenwood Springs, Colorado (subcontractor report)

Final Report-Dickinson Geothermal Study, Dickinson, North Dakota (subcontractor report)

\section{CANCELLED}

Comparison of Two Options for Supplying Geothermal Energy to the Veterans Administration Medical Center, Marlin, Texas (subcontractor report)

Geothermal Utilization at Castle Oaks Subdivision Castle Rock, Colorado (subcontractor report)

Space Heating for Twin Lakes School Near Gallup, New Mexico (subcontractor report)

Pumping Tests of Well Campbell et al. No. 2, Gila Hot Springs, Grant County, New Mexico (subcontractor report)

Geothermal Deicing of Highways and Bridge structures

Assessment of a Geothermal Application at Tucson, Arizona 
GTA

Report Number

26.

27.

28.

29.
EG\&G

Report Number

*EGG-GTH-5741

EGG-GTH-5779

EGG-GTH-5804

Pipe Selection Guide

An Overview of Engineering and Agricultural Design Considerations of the Raft River Soil-Warming and Heat-Dissipation Experiment

Design of the Glenwood Springs Downhole Heat Exchanger

*Published as of $4 / 1 / 82$. 
].

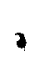




\section{PREFACE}

This report was prepared for EG\&G Idaho by Radian Corporation on Subcontract No. K-7920 under the Department of Energy's Outreach Program. It is being reissued without modification as an EG\&G Formal report in order to make it available to others who may be interested in this geothermal application. 


\section{ABSTRACT}

The objective of this project was to compare two options for supplying geothermal energy to the Veterans Administration Medical Center (VAMC) at Marlin, Texas. One option is to drill a new production well on the VAMC property, and the other is to construct a $6900-\mathrm{ft}$ pipeline from an existing geothermal well to the VAMC. Technical, economic, regulatory, and institutional issues were examined during the comparison. It was concluded that neither option possesses any significant cost or regulatory advantage over the other. The new well option does involve a risk, probably small, of hitting the expected geothermal resource, whereas the pipeline option involves no similar risk. However, the pipeline option will require right-of-way negotiations and a contractual agreement between the VAMC and the owners of the existing geothermal well. Assuming that a new well is successful, that option appears to be in the best interest of the VAMC. 
COMPARISON OF TWO OPTIONS FOR SUPPLYING GEOTHERMAL ENERGY TO THE VETERANS ADMINISTRATION MEDICAL CENTER AT MARLIN, TEXAS

\author{
Thomas F. Green \\ Principal Investigator \\ Prepared for: \\ Veterans Administration Medical Center \\ Marlin, Texas
}

Under Subcontract No. K-7920 to:

EG\&G Idaho, Inc and

the U.S. Department of Energy

Under Contract No. DE-AC07-76ID01570

P.O. Box 1625

Idaho Falls, Idaho 83415

Final Report

March 22, 1982 


\section{$\underline{\text { ABSTRACT }}$}

The objective of this project was to compare two options for supplying geothermal energy to the Veterans Administration Medical Center (VAMC) at Marlin, Texas. One option is to drill a new production well on the VAMC property, and the other is to construct a 6900 foot pipeline from an existing geothermal well to the VAMC. Technical, economic, regulatory, and institutional issues were examined during the comparison. It was concluded that neither option possesses any significant cost or regulatory advantage over the other. The new well option does involve a risk, probably smal1, of hitting the expected geothermal resource, whereas the pipeline option involves no similar risk. However, the pipeline option will require right-of-way negotiations and a contractual agreement between the VAMC and the owners of the existing geothermal well. Assuming that a new well is successful, that option appears to be in the best interest of the VAMC. 
BACKGROUND AND SUMMARY . . . . . . . . . . . . . . . . . 1

Background . . . . . . . . . . . . . . . . . . . 1

Summary . . . . . . . . . . . . . . . . 2

GEOTHERMAL SUPPLY SYSTEM OPTIONS . . . . . . . . . . . . . 5

VAMC Heating Loads and Backup Options . . . . 5

Production System Using a New Well . . . . . . . 6

Production System Using Pipeline from

T-H-S to the VAMC . . . . . . . . . . . . . . . 9

GEOTHERMAL DISPOSAL OPTIONS . . . . . . . . . . . . . . . 16

Injection . . . . . . . . . . . . . . . . . . . 16

Surface Discharge . . . . . . . . . . . . . 17

CONCLUSIONS . . . . . . . . . . . . . . . . . . . 21

REFERENCES . . . . . . . . . . . . . . . . . . 23

APPENDIX . . . . . . . . . . . . . . . . . . . . . . . 24 


\section{LIST OF TABLES}

TABLE 1. SUMMARY OF MARLIN GEOTHERMAL WELLS...... $\frac{\text { Page }}{1}$

TABLE 2. SUMMARY OF ESTIMATED COSTS FOR TWO

GEOTHERMAL SUPPLY OPTIONS . . . . . . . . . . . . . . 4

TABLE 3. SUMMARY OF PERMITS AND REPORTS GOVERNING

NEW GEOTHERMAL PRODUCTION . . . . . . . . . . 8

TABLE 4. SUMMARY OF PIPELINE COST ESTIMATES . . . . . . 11

TABLE 5. ESTIMATED ANNUAL COSTS FOR UTILITIES AND

PRODUCTION PUMP SINKING FUND (PIPELINE

OPTION) . . . . . . . . . . . . . . . . . . . . 14

TABLE 6. SUMMARY OF PERMITS GOVERNING GEOTHERMAL

PIPELINE . . . . . . . . . . . . . . . . . . . 15

TABLE 7. SUMMARY OF ESTIMATED COSTS FOR TWO

TABLE A-1. PIPELINE ESTIMATE SUMMARY . . . . . . . . . . 29

\section{LIST OF FIGURES}

$\underline{\text { Page }}$

Figure 1. Preliminary Production System Schematic
for New Well Option . . . . . . . . 7

Figure 2. Preliminary Routing for Geothermal $\quad$ Pipeline... . . . 10

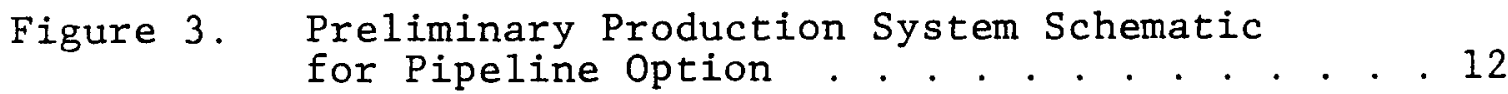

Figure 4. Possible Surface Discharge Routes for
VAMC Geothermal Project . . . . . . . . . 18

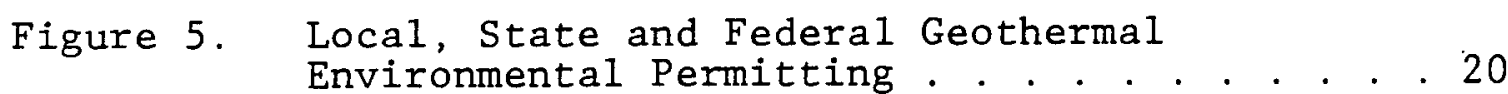

Figure A-1. Pipeline Routing Data Supplied to
Utility Contractors . . . . . . . . . . 27 


\author{
COMPARISON OF TWO OPTIONS FOR \\ SUPPLYING GEOTHERMAL ENERGY \\ TO THE VETERANS ADMINISTRATION \\ MEDICAL CENTER AT MARLIN, TEXAS \\ BACKGROUND AND SUMMARY
}

\title{
Background
}

Marlin, Texas, overlies a known geothermal resource area, and has been known for its hot mineral wells for many years. Four existing geothermal wells, summarized in Table 1, are evidence of this resource.

TABLE 1. SUMMARY OF MARLIN GEOTHERMAL WELLS

\begin{tabular}{|c|c|c|c|c|c|c|c|c|}
\hline Well No. & Owner & $\begin{array}{c}\text { Date } \\
\text { Drilled }\end{array}$ & $\begin{array}{l}\text { Depth } \\
(\mathrm{Ft})\end{array}$ & $\begin{array}{l}\text { Temp } \\
\stackrel{\left({ }^{\circ} \mathrm{F}\right)}{ } \\
\end{array}$ & $\begin{array}{l}\text { Current } \\
\text { Shut In } \\
\text { Pressure } \\
\text { (PSIG) } \\
\end{array}$ & $\begin{array}{c}\text { Tocal } \\
\text { Dissolved } \\
\text { Solds } \\
\text { (PPM) } \\
\end{array}$ & $\begin{array}{c}\text { Current } \\
\text { Utilization }\end{array}$ & $\begin{array}{c}\text { Current } \\
\text { vell } \\
\text { Status } \\
\end{array}$ \\
\hline 1 & City of Marlin & 1893 & 3350 & $122^{1}$ & 60 & $-10,000$ & $\begin{array}{l}\text { Space Heating } \\
\text { for Chamber of } \\
\text { Commerce Offices }\end{array}$ & Flowing \\
\hline 2 & $\begin{array}{l}\text { Centex Savings } \\
\text { and Loan }\end{array}$ & 1909 & 2400 & $128^{2}$ & $\mathrm{NA}^{3}$ & $\mathrm{NA}$ & NA & Terminated \\
\hline 3 & $\begin{array}{l}\text { Centex Savings } \\
\text { and Loan }\end{array}$ & 1909 & 3300 & $134^{2}$ & NA & $\mathrm{NA}$ & $\mathrm{NA}$ & Shut In \\
\hline 4 & $\begin{array}{l}\text { Torbetc-Hutchings- } \\
\text { Smith Memorial } \\
\text { Hospital }\end{array}$ & 1979 & 3900 & 153 & 6 & $-4,000$ & $\begin{array}{l}\text { Water and Space } \\
\text { Heating for T-H-S } \\
\text { Memorial Hospital }\end{array}$ & Flowing \\
\hline
\end{tabular}

${ }^{1} 147^{\circ} \mathrm{F}$ reported when well was drilled, $122^{\circ} \mathrm{F}$ is current temperature at a production rate of $-20 \mathrm{gpm}$.

${ }^{2}$ Reported.

${ }^{3}$ Not available or not applicable.

Today, Well No. 1 is still flowing. Its waters provide heating for the Marlin Chamber of Commerce offices. Well No. 2 was terminated in 1967 when Well No. 3 was reworked. Well No. 3 has been shut in since about 1970. Each of these older wells produces primarily from the highly mineralized Glen Rose Formation. 
Well No. 4, the newest of these wells, was completed in 1979 as part of the Torbett-Hutchings-Smith (T-H-S) Memorial Hospital Geothermal Project. It is this well which demonstrates the availability of hotter and cleaner geothermal waters at depths slightly deeper than the three older wells. This 3900 foot well completely penetrates the Hosston formation and produces $155^{\circ} \mathrm{F}$ water having a total dissolved solids (TDS) content of approximately $4000 \mathrm{ppm}$. The capacity of this well is approximately $450 \mathrm{gpm}$, of which the T-H-S Hospital uses approximately $150 \mathrm{gpm}$ at peak loads.

The Veterans Administration Medical Center (VAMC) at Marlin has followed with interest the progress of the soon-to-be completed T-H-S Memorial Hospital geothermal project. The VAMC commissioned an energy audit and feasibility study which included a preliminary assessment of geothermal feasibility for the VAMC. The report for this study was issued in 1980 (Ref. 1). That work assumed that a new production well would be drilled on VAMC property. However, the geothermal waters can now also be supplied to the VAMC via a pipeline from the existing $\mathrm{T}-\mathrm{H}-\mathrm{S}$ well. This report presents results of a comparison between these two options.

\section{Summary}

The objective of this project was to compare the cost of the two options for supplying hot geothermal waters to the VAMC. One option, addressed also in Reference 1 , is to drill a new production well at the VAMC. The other is to construct a pipeline from the existing T-H-S well to the VAMC property.

These two options were investigated to determine their technical and economic merits. In addition, regulatory and institutional facets were addressed. Remaining sections of the report detail this investigation. 
Results of the economic investigation in Table 2 show that neither option possesses any significant advantage over the other with respect to costs. The decision to use a new well or a pipeline should therefore be based on other factors, such as the probability of drilling a successful well on the first try, regulatory requirements, requirements for pipeline right-of-way negotiations, and legal and logistical issues for a pipeline between the T-H-S Hospital and the VAMC. These factors seem to suggest that a new production well is in the best interest of the VAMC, assuming that a single well is successful in hitting the expected resource. Before proceeding with well drilling, detailed engineering, bid procurement and geothermal heating system construction, the following three actions are recommended.

- Perform a detailed, site-specific investigation to determine best production well siting and expected success.

- Perform needed analyses and apply for conditional permits to surface discharge based on an assumed water quality similar to the T-H-S fluid.

- Identify potential partners to share the geothermal production well and therefore reduce the costs of the well to the VAMC.

The second step will allow a determination of surface discharge acceptance prior to incurring the cost of drilling a new production well. Outcomes from both the first and second steps are expected to be favorable to geothermal project continuation. The third step is included because it has the potential benefit of further improving of the geothermal cost-effectiveness. It should be noted, however, that finding such well partners is not a prerequisite for a cost-effective system. 
TABLE 2. SUMMARY OF ESTIMATED COSTS FOR

TWO GEOTHERMAL SUPPLY OPTIONS

\begin{tabular}{|c|c|c|}
\hline \multirow[t]{3}{*}{$\begin{array}{l}\text { New Production } \\
\text { Wel1 }\end{array}$} & $\begin{array}{l}\text { - Drill, complete, develop, } \\
\text { and test one new well }\end{array}$ & $\$ 300,000$ \\
\hline & $\begin{array}{l}\text { - Production pump assembly } \\
\text { for new well }\end{array}$ & 48,900 \\
\hline & ESTIMATED TOTAL & 348,900 \\
\hline \multirow{3}{*}{$\begin{array}{l}\text { Pipeline from } \\
\text { Existing } \mathrm{T}-\mathrm{H}-\mathrm{S} \\
\text { Well }\end{array}$} & $\begin{array}{l}\text { - Construct pipeline from } \\
\text { T-H-S to VAMC }\end{array}$ & 285,800 \\
\hline & $\begin{array}{l}\text { - Revise production system } \\
\text { to accommodate two users } \\
\text { (T-H-S and VAMC) }\end{array}$ & 66,100 \\
\hline & ESTIMATED TOTAL & $\$ 351,900$ \\
\hline
\end{tabular}

${ }^{1}$ Based on average of five estimates rather than the lowest estimate. 
GEOTHERMAL SUPPLY SYSTEM OPTIONS

\section{VAMC Heating Loads and Backup Options}

A geothermal supply system must be able to readily provide the $150 \mathrm{gpm}$ flow required to meet the $3.8 \times 10^{6} \mathrm{Btu} / \mathrm{hr}$ peak load reported by Huds on (Ref. 1). This load includes both the water and space heating demands for the 222-bed VAMC.

Currently, space heating for the hospital is accomplished with steam radiators, and space cooling is accomplished with a two-pipe chilled water circulation system. To effect a geothermal changeover, the steam radiator system would be abandoned or used for emergency backup only, and the twopipe chilled water system would operate as a two-pipe heating water system during heating periods. These modifications should be neither extensive or expensive. Flat plate heat exchangers would be used to transfer the heat from the geothermal waters to the heating waters.

Emergency backup heating can be provided in several ways. Hot water generators can be leased on short notice for emergency situations. A tandem downhole pump assembly (two parallel downhole pumps) with an emergency generator tie-in could also be used. 
The producing well could also be designed to allow a third independent pump to be used. This pumping station could be sold at an appropriate pro-rata cost to another user, thereby decreasing the production well costs to the VAMC.

\section{Production System Using a New Well}

The only significant technical issue that exists for the new well option is whether or not the site specific resource conditions beneath the VAMC property are sufficient to produce the expected flows and temperatures. Although the probability of this occurring is high, the question cannot be completely resolved unless the well is actually drilled. If, as expected, such a new well were successful, it should produce geothermal waters at approximately $150^{\circ} \mathrm{F}$ and $4000 \mathrm{ppm}$ of total dissolved solids (TDS). This well would be similar to the existing $\mathrm{T}-\mathrm{H}-\mathrm{S}$ well. A preliminary schematic of such a new well and its pumping system is provided in Figure 1. As noted above, this well design could be refined if other users were identified or if a tandem pump assembly were used for emergency backup.

The estimated cost of a new well similar to Figure 1 , as reported in Reference 1 , is approximately $\$ 310,000$. Radian obtained an independent estimate for the well during this project which totaled $\$ 290,000$ (Ref. 2). This latter estimate assumes the well is drilled in 1982. Both estimates agree closely so that the actual cost of the new production well, if drilled during 1982, should be approximately $\$ 300,000$. 


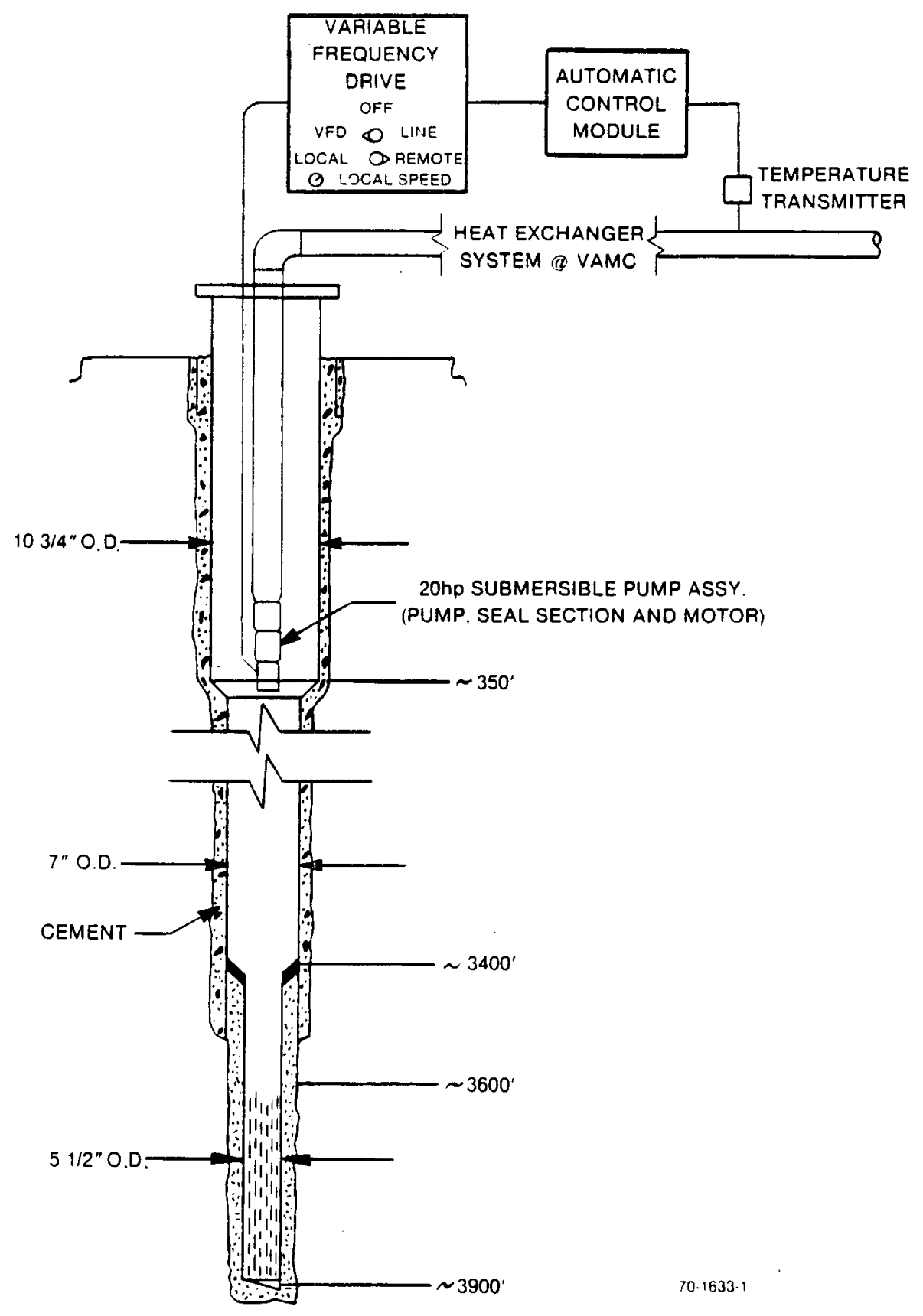

Figure 1. Preliminary Production System Schematic for New Well Option 
In addition to this well cost, a production pump with appropriate controls will be required to complete the production system. The installed cost of the pump, variable frequency drive, transformers, cross-the-1ine bypass, and controls is approximately $\$ 48,900$. The total cost for the production system using a new well is therefore approximately $\$ 348,000$.

Several permits will be required for drilling, completing, developing, and testing a new production well. These permits are summarized in Table 3 . There are no difficulties expected in securing any of these production well permits.

TABLE 3. SUMMARY OF PERMITS AND REPORTS GOVERNING NEW GEOTHERMAL PRODUCTION WELLS

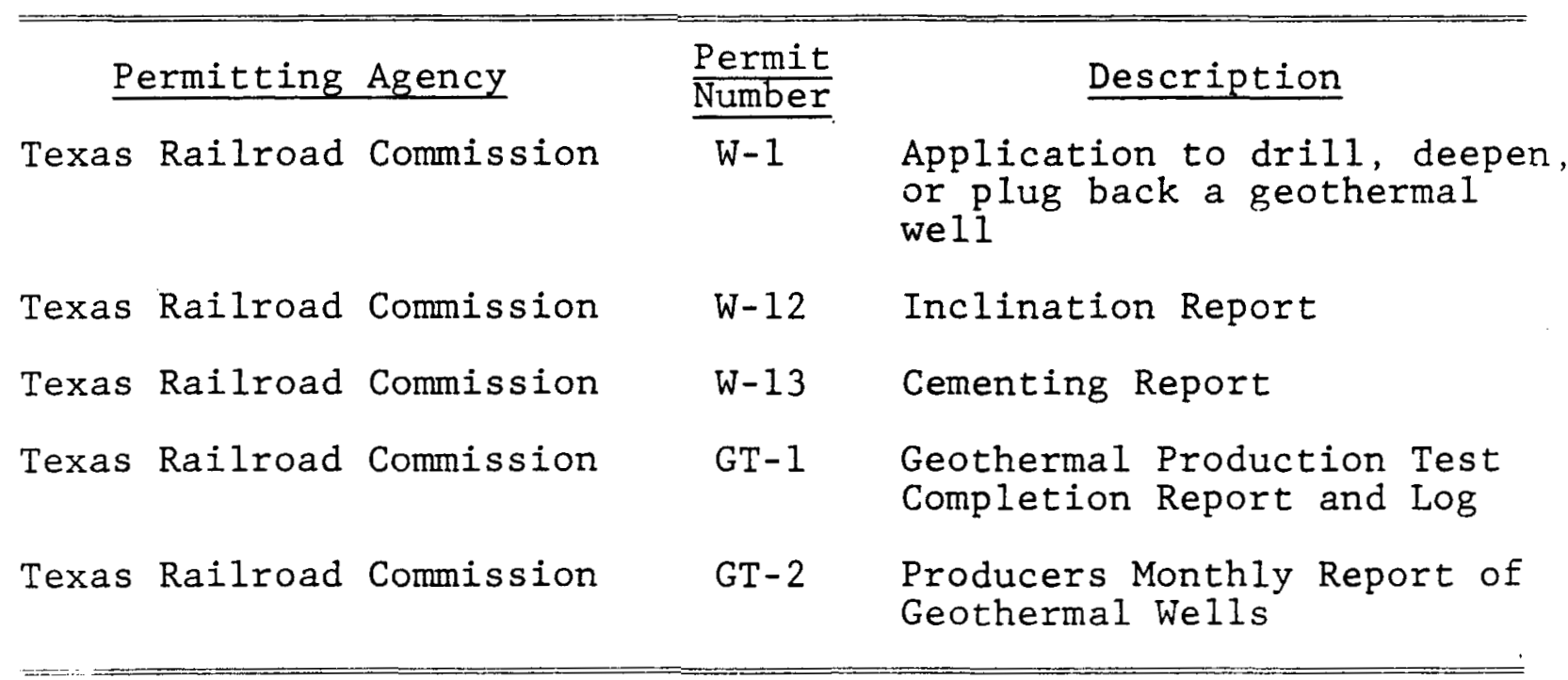




\section{Production System Using Pipeline from $\mathrm{T}-\mathrm{H}-\mathrm{S}$ to the VAMC}

The other option of supplying hot geothermal water to the VAMC is to pipe it from the existing T-H-S Memorial Hospital well. There are no apparent technical obstacles for this option. The existing well has more than enough capacity to meet the 150 gpm peak loads of each hospital. Temperature losses at maximum flow of approximately $150 \mathrm{gpm}$ will be less than $2^{\circ} \mathrm{F}$, and losses at minimum flows of approximately $50 \mathrm{gpm}$ will be less than $5^{\circ} \mathrm{F}$. The pertinent factors are therefore economic and institutional rather than technical.

In order to assess the cost of the pipeline, a prospective route was first selected. Figure 2 illustrates this route, which requires approximately $6900 \mathrm{feet}$ of insulated 4-inch CPVC pipe. Although a more desirable route would be to follow the Missouri-Pacific (Mo-Pac) Railroad right-of-way, it appears very doubtful that permission from the Railroad could be secured without extensive, time-consuming and possibly costly negotiations (Ref. 3 ).

The route selected therefore interfaces minimally with the Mo-Pac right-of-way. Instead, it predominantly follows a city right-of-way designed to minimize the more expensive excavation through paved (often concrete-based) streets. The Marlin City Council has the approval authority for such use of the right-of-way, and it is expected that the Council would be cooperative (Ref. 4). In addition, the proposed route requires minimal negotiations with property owners since no more than five would be affected.

An engineering estimate for the cost of this geothermal pipeline was made by Radian. In addition, five utility 


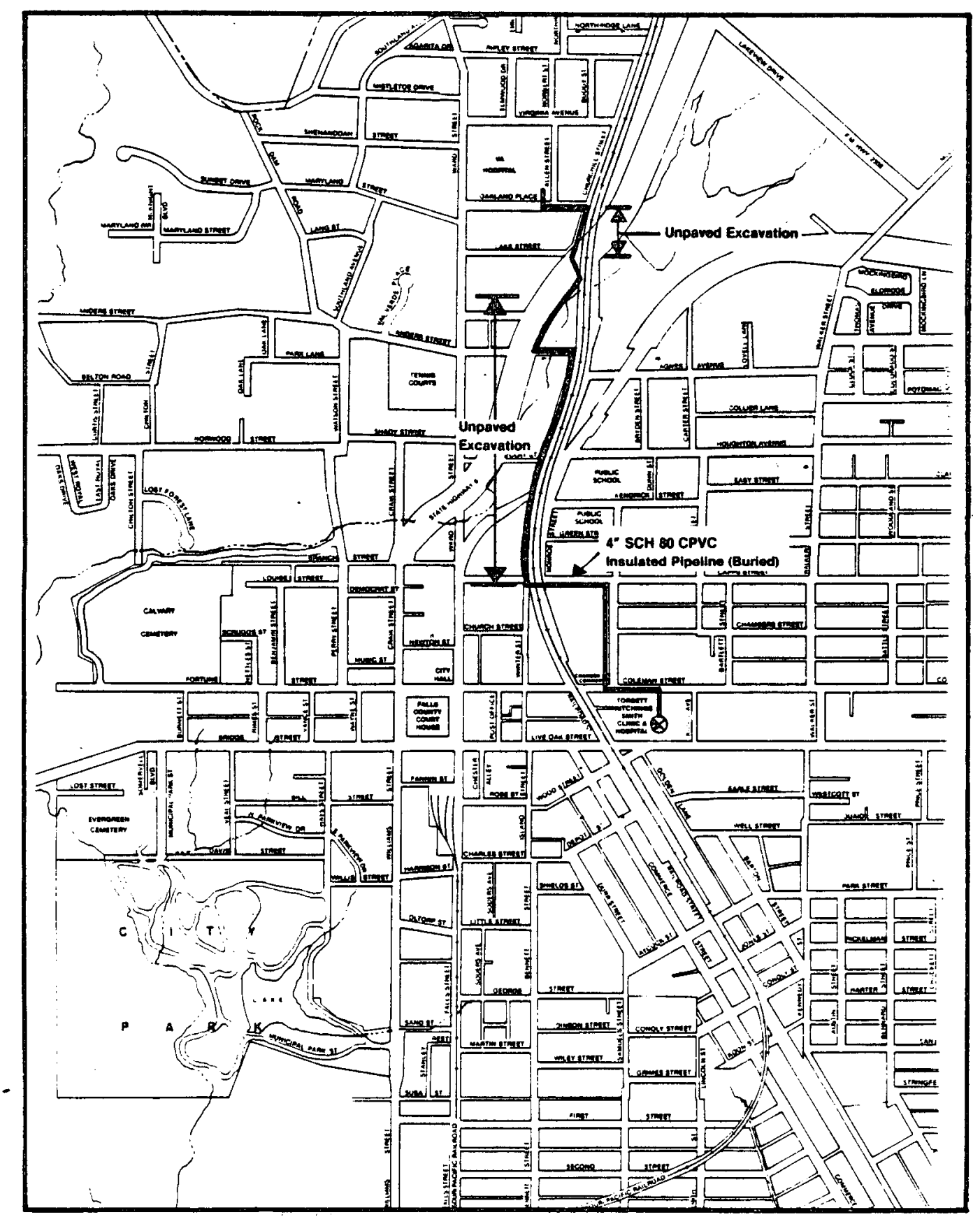

Figure 2. Preliminary Routing for Geothermal Pipeline 
contractors in the Marlin area were contacted and asked to provide estimates based on a preliminary pipeline design and specification. (The preliminary design and specification are provided in the appendix.)

A summary of the four estimates received is provided in Table 4. The low estimate is $\$ 208,800$ and the average estimate is $\$ 285,000$. The average will be used for comparing costs of the well and pipeline options, although a low bid would probably be selected if the pipeline were constructed.

TABLE 4. SUMMARY OF PIPELINE COST ESTIMATES ${ }^{1}$

\begin{tabular}{cc}
\hline Contractor & $\frac{\$}{208,800}$ \\
A & 303,500 \\
B & 261,400 \\
C & 365,000 \\
Radian Engineering Estimate & $\underline{290,100}$ \\
Average & 285,800 \\
\hline
\end{tabular}

${ }^{1}$ Cost of uninsulated disposal line described later in GEOTHERMAL DISPOSAL OPTIONS included.

In addition to the pipeline costs, the existing $20 \mathrm{hp}$ production system at the T-H-S well will have to be modified. One method of accomplishing the revision with minimal cost while still maintaining control flexibility is to use a 30 hp production pump assembly and two surface pump assemblies. This production system is shown schematically in Figure 3. The cost of revising the existing production system to that needed for the pipeline is approximately $\$ 66,100$. It is assumed that the VAMC will bear the complete cost of this revision. 


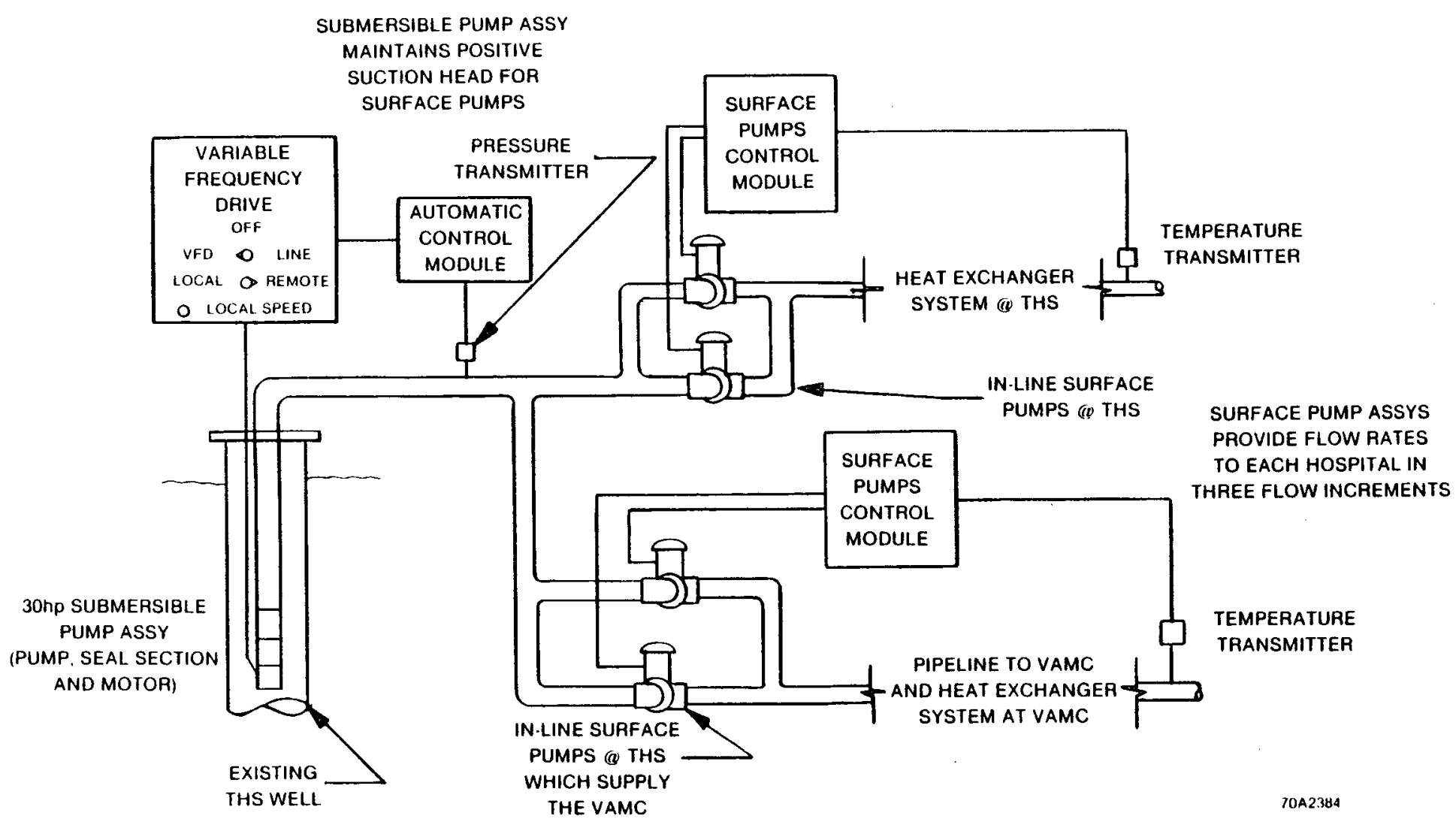

Figure 3. Preliminary Production System Schematic for Pipeline Option 
Since the production system in the pipeline option will most likely be located at the T-H-S well site, the T-H-S Hospital will bear the utility costs of operating the pumps. It is reasonable to expect that the T-H-S Hospital will require reimbursement of these utility costs from the VAMC. A sinking fund for maintenance and eventual replacement of the submersible pump may also be required. It was assumed that a charge for the $\mathrm{T}-\mathrm{H}-\mathrm{S}$ well water or for delivered energy would not be assessed.

To implement the pipeline strategy, an agreement between the T-H-S hospital and the VAMC will be needed. In addition to any legal issues which may need to be resolved, this agreement may include provisions for utility costs and perhaps a sinking fund contribution. The cost to the VAMC for its expected annual consumption of approximately 50 million gallons will depend upon the nature of the agreement reached. As shown in Table 5, if the VAMC is required to underwrite the total utility and sinking fund expenses, an annual charge of approximately $\$ 9000$ will result. If the VAMC is required to underwrite the entire sinking fund but only its share of utilities, an annual charge of approximately $\$ 7900$ will result. Similarly, if the VAMC and T-H-S Hospital split these expenses, a $\$ 4500$ cost to the VAMC will result.

It should be recognized that the utility and sinking fund costs are not necessarily exclusive to the pipeline option. The VAMC will also incur production system utility costs in the new well option. The larger sinking fund cost may or may not exist in the new well option, depending on VAMC financing policies and procedures. For these reasons, the utilities and sinking fund are not considered in the comparison between the two geothermal supply options. 
TABLE 5. ESTIMATED ANNUAL COSTS FOR UTILITIES

AND PRODUCTION PUMP SINKING FUND

(PIPELINE OPTION)

\begin{tabular}{|c|c|c|c|c|}
\hline & Case & $\begin{array}{l}\text { Estimated } \\
\text { Annual } \\
\text { Production } \\
\text { Utilities }^{1}\end{array}$ & $\begin{array}{l}\text { Annual } \\
\text { Sinking Fund } \\
\text { for Maintenance } \\
\text { and Pump Assy } \\
\text { Replacement }\end{array}$ & $\begin{array}{c}\text { Total } \\
\text { Annual Cost }\end{array}$ \\
\hline 1 . & $\begin{array}{l}\text { VAMC underwrites } \\
\text { entire cost of } \\
\text { operating, maintain- } \\
\text { ing, and eventually } \\
\text { replacing the pro- } \\
\text { duction pump assy. }\end{array}$ & $\begin{array}{l}\$ 2,300 \\
(55,000 \mathrm{kwh})\end{array}$ & $\$ 6,700$ & $\$ 9,000$ \\
\hline 2 . & $\begin{array}{l}\text { VAMC underwrites } \\
\text { entire cost of } \\
\text { maintaining and } \\
\text { eventually replacing } \\
\text { production pump assy, } \\
\text { but only pays its } \\
\text { share of production } \\
\text { system utilities }\end{array}$ & $\begin{array}{l}\$ 1,200 \\
(28,000 \mathrm{kwh})\end{array}$ & $\$ 6,700$ & $\$ 7,900$ \\
\hline 3. & $\begin{array}{l}\text { VAMC and T-H-S } \\
\text { split utilities, } \\
\text { maintenance, and } \\
\text { eventual replacement } \\
\text { of production pump } \\
\text { assy. }\end{array}$ & $\begin{array}{c}\$ 1,200 \\
(28,000 \mathrm{kwh})\end{array}$ & $\$ 3,300$ & $\$ 4,500$ \\
\hline
\end{tabular}

1 Equates to $\$ 0.04 / \mathrm{kwh}$ if metered directly or $\$ 0.024 / 1000 \mathrm{gal}$ if metered on geofluid consumption

2 Equates to $\$ 0.14 / 1000$ gal: $\$ 0.02 / 1000$ gal for maintenance and $\$ 0.12 / 1000$ gal for pump replacement 
Like the new well option, the pipeline option requires regulatory attention. Table 6 lists those permits which may be required for the pipeline option.

TABLE 6. SUMMARY OF PERMITS GOVERNING GEOTHERMAL PIPELINE

\begin{tabular}{|c|c|c|c|}
\hline Permitting & Agency & $\frac{\text { Permit }}{\text { Number }}$ & Description \\
\hline Texas Railroad & Commission & $\mathrm{GT}-4$ & $\begin{array}{l}\text { Producers Certificate of } \\
\text { Compliance and Authoriza- } \\
\text { tion to transport geothermal } \\
\text { energy }\end{array}$ \\
\hline Texas Railroad & Commission & $\mathrm{T}-4$ & $\begin{array}{l}\text { Application for Permit } \\
\text { to operate pipeline in Texas }\end{array}$ \\
\hline Texas Railroad & Commission & $\mathrm{T}-4 \mathrm{~A}$ & Permit to Operate pipeline \\
\hline Texas Railroad & Commission & $\mathrm{T}-4 \mathrm{C}$ & $\begin{array}{l}\text { Pipeline and gathering } \\
\text { system form of certification }\end{array}$ \\
\hline
\end{tabular}


GEOTHERMAL DISPOSAL OPTIONS

Although an assessment of geothermal disposal issues was not included in the scope of this project, a brief discussion of this matter is warranted. Two basic disposal options exist for each geothermal supply option. One is injection and the other is surface discharge.

\section{Injection}

Injection of the spent geothermal waters into the producing formation is usually considered to be the most environmentally pristine method of geothermal disposal. The federal Underground Injection Control (UIC) program currently considers geothermal waters as a "Class 5 " waste. This classification means that the UIC program considers geothermal injection to be a very low priority, low impact problem. Consequently, there are currently no federal regulations governing the injection of geothermal waters. And no future federal regulations are expected since the states are currently receiving UIC program control from the federal government as suitable state programs are adopted.

The Texas Railroad Commission currently has state jurisdiction over injection of geothermal fluids, and will retain this jurisdiction once the UIC program is passed to the state. Currently, filing the GT-5 (application to inject fluid into a formation productive of geothermal resources) is the only regulatory permit requirement. If injection is used, there are no expected difficulties in obtaining the permit. 
Technical and economic issues surrounding injection usually make it a less desirable disposal option than surface discharge. Careful planning of the production/injection well couplet is required to eliminate communication between the wells. Such communication can allow the cooler injected fluid to circulate back to the production well before it has been reheated by the reservoir. Thus production temperatures fall and geothermal usefulness is decreased. Careful design of the injection well itself is also critical since injection pressures and capacities as well as reservoir plugging tendencies can produce injection well problems.

\section{Surface Discharge}

When environmentally acceptable, surface discharge is considered to be the more favorable disposal technique. It requires neither the costly and often troublesome injection well nor the large injection pump(s) which consume substantial amounts of energy. It does, however, require a relatively clean geothermal fluid, an acceptable surface discharge route, and the absence of potential subsidence problems. The VAMC site appears to have each of these requirements. It is therefore quite conceivable that surface discharge will be an appropriate disposal candidate for a VAMC geothermal project.

Figure 4 shows two surface discharge alternatives. In one case, the spent geothermal waters would be discharged via a storm drain to the Oil Mill Lake. In the other case, the waters would be discharged into a surface drainage ditch that drains the Oil Mill Lake. This latter case is reflected in the pipeline costs presented earlier in Table 4. In either case, the discharged waters would flow from the drainage ditch into Bean Branch, on to McCullough Slough, and eventually to the Brazos River. With the exception of the drainage ditch, this route is the same that is currently permitted for surface discharge in the $\mathrm{T}-\mathrm{H}-\mathrm{S}$ system. 


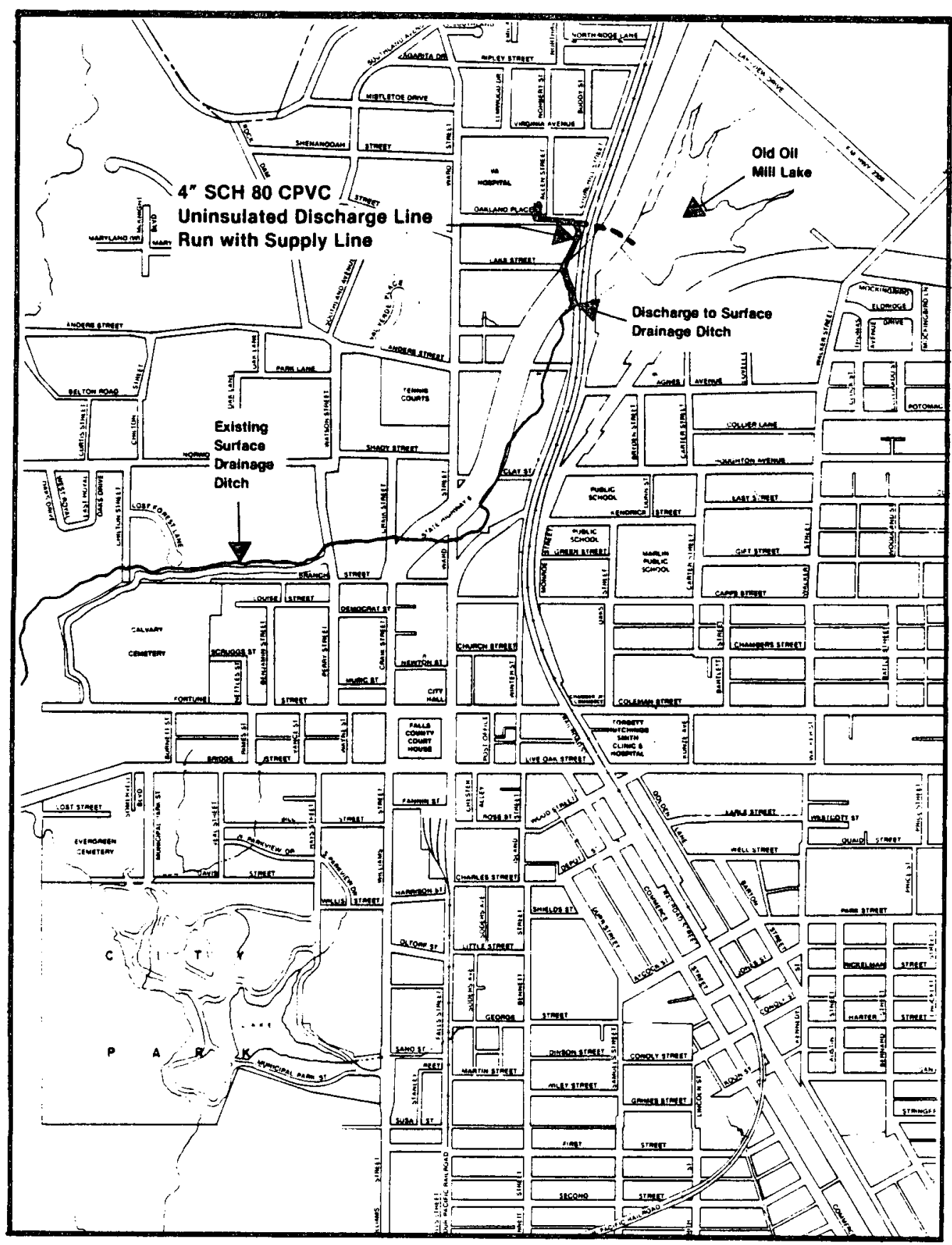

Fj.gure 4. Possible Surface Discharge Routes for VAr!C Geothermal Project 
Although an analysis on these surface discharge options has not been performed, it is expected that no significant environmental impact would result. Also, no subsidence is expected since production would occur from a highly consolidated sandstone formation.

To achieve surface disposal, several environmental reviews are required. Figure 5 summarizes these as well as the one required for injection. The bold tracks in Figure 5 are the anticipated outcomes of environmental permitting.

Although not usually considered feasible because of cost, treatment of spent geothermal waters may be a competitive "disposal" technique in some instances. Preliminary estimates by Radian show that geothermal waters expected for the VAMC can be treated to potable quality at a cost of roughly $\$ 1.30 / 1000$ gal. Comparing this figure to recently adopted water rates in Marlin indicates that water treatment may be an economically viable disposal alternative if a need exists for the potable water effluent. 


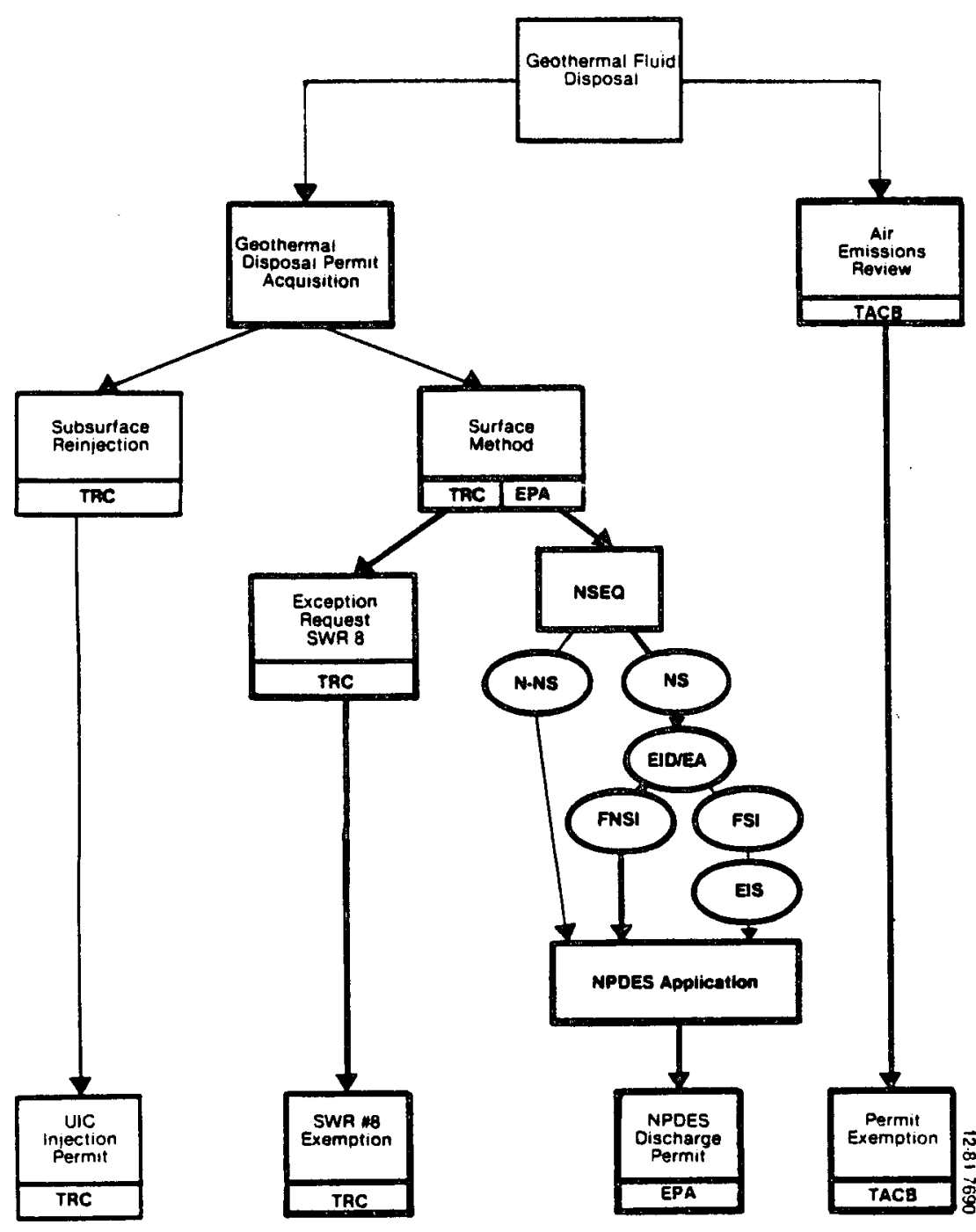

ABEREVIATIONS

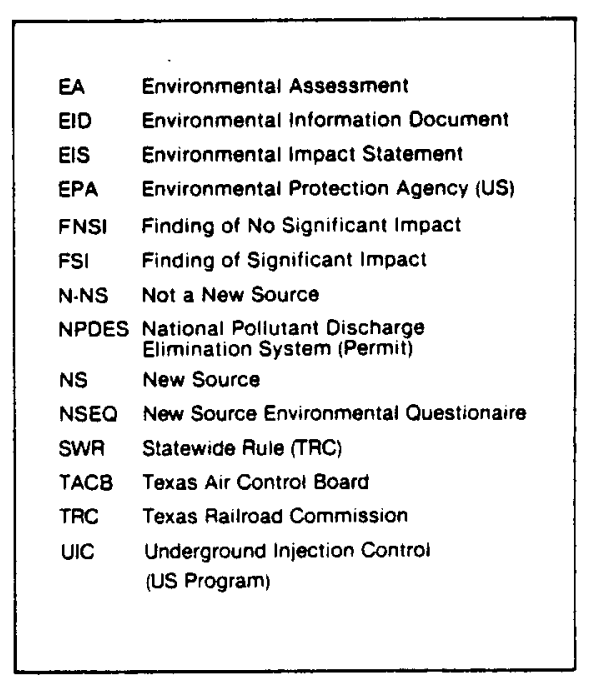

Figure 5. Local, State and Federal Geothermal Environmental Permitting 


\section{CONCLUSIONS}

Table 7 summarizes costs of the two geothermal supply options investigated in this project. As shown, the expected costs for the options are very close so that neither option possesses any apparent economic advantage over the other. The decision to use a new well or a pipeline must therefore rest primarily on factors other than costs.

TABLE 7. SUMMARY OF ESTIMATED COSTS FOR TWO GEOTHERMAL SUPPLY OPTIONS

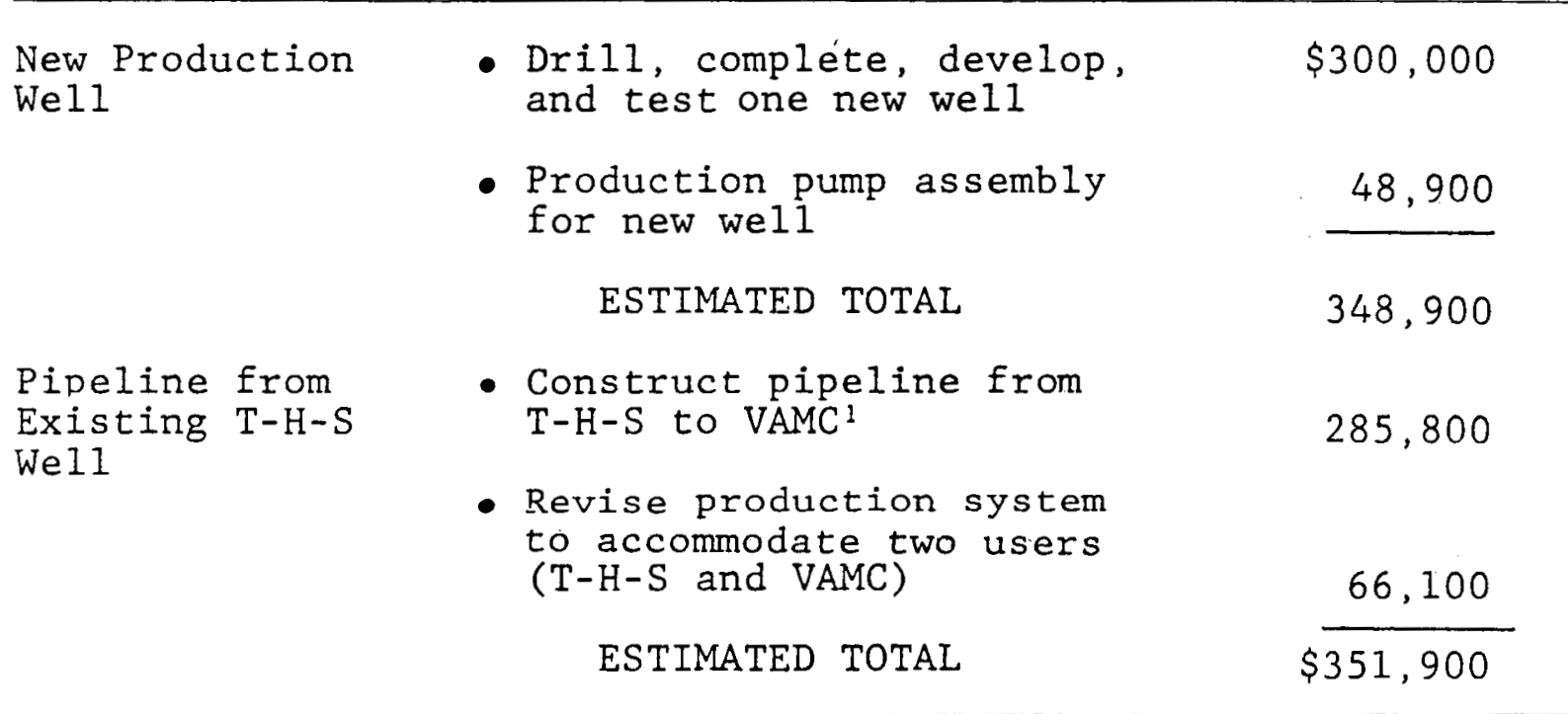

${ }^{1}$ Based on average of five estimates rather than the lowest
estimate. 
Assuming that a new VAMC well is successful in hitting the expected geothermal resource, it appears that the new well option is in the best interest of the VAMC. A new well will require no right-of-way negotiations with the city, property owners, or the Missouri-Pacific Railroad. Also, there appears to be no regulatory advantage of using a pipeline rather than a well. If appropriately designed, this new well could also be simultaneously leased to surrounding parties without sacrificing any reliability to the VAMC system, thus providing a means of recuperating some of capital costs of the well. Finally, regardless of the supply system used, a VAMC geothermal project is an attractive candidate for surface disposal of the spent waters.

The following steps are recommended in proceeding with a geothermal project for the VAMC.

- Perform a detailed site-specific investigation to determine best production well siting and expected success,

- Perform needed analyses and apply for conditional permits for surface discharge based on an assumed water quality similar to the T-H-S fluid. (This step will allow a determination of surface discharge acceptance prior to incurring the cost of drilling a production well.)

If, as expected, the outcome of the two steps is favorable, the production well can be drilled. If the drilling is successful, detailed engineering for the geothermal heating system can occur, bids can be secured, and the system can be constructed. 
1. Huds on Engineering Corporation, Phase II Energy Audit/ Feasibility Study for Veterans Administration Health Care Facility, Marlin, Texas, Revised April 18, 1980.

2. Private communication between R.A. Belan of Radian Corporation and Joe Dillard of J.L. Meyer Drilling, December 7, 1981.

3. Private communication between T.F. Green of Radian Corporation and Bill Tillman of the Missouri-Pacific Railroad, December 2,1981 .

4. Personal communication between T.F. Green of Radian Corporation and A.C. Johnson, Marlin City Manager, December 1981. 


\section{APPENDIX}

Provided below is a copy of the preliminary pipeline design information supplied to each utility contractor who provided cost estimates. Included are the cover letter, a map of the proposed routing, details of the burial, and a summary sheet. 
December 23, 1981

$212-016-\mathrm{XX}$

Subject: Request for Geothermal Pipeline Cost Estimate

The Veteran's Administration Medical Center (VAMC) of Marlin, Texas, is pursuing the feasibility of using geothermal energy to provide water and space heating for the facility. Two methods for supplying the geothermal fluid (hot water) to the VAMC exist:

1) Drill and complete a new 3900 Et geothermal well to produce the needed hot water.

2) Install a pipeline for the VAMC from the recently completed well at Torbett-Hutchings-Smith (T-H-S) Memorial Hospital. (A system similar to the one proposed for the VAMC is near completion at T-H-S.)

Radian Corporation has been commissioned to compare the costs of these two alternatives. Our engineering cost estimates indicate that the pipeline may be the less expensive alternative as well as also possessing other benefits. We would like to verify our estimate with a contractor estimate prior to making recommendations to the VAMC.

I am therefore asking that you provide us with a fixed price estimate (not a firm bid) for installing the pipeline from $\mathrm{T}-\mathrm{H}-\mathrm{S}$ to the VAMC. Briefly, the job entails installing approximately 6910 feet of insulated CPVC pipe and 950 feet of uninsulated CPVC pipe. Your estimate should include all surveying, excavation and repair, materials, pressure testing, as-built drawings, profit and insurance for completing the job on a fixed price competitive bid award. Assume the job starts in October 1982.

The attached sheets should provide sufficient information for you to arrive at a reasonably accurate figure with minimal effort. Those sheets include a map showing general pipeline routing and typical details for pipeline burial. 
I will be most pleased to receive your estimate, either written or orally, at your earliest opportunity. If you have any questions, please feel free to call.

Sincerely,

Tom Green

Senior Engineer

Radian Corporation 


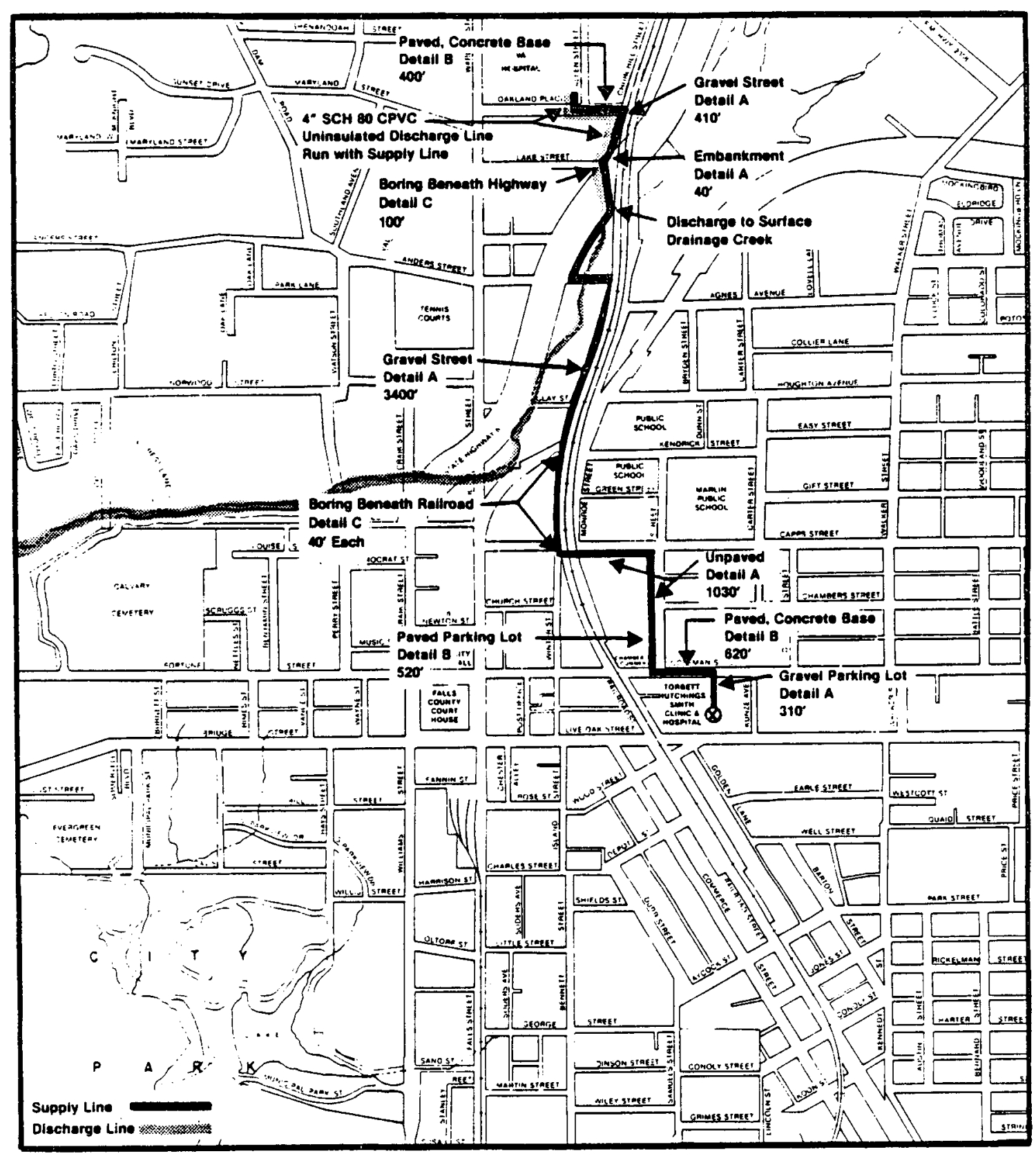

Figure A-1. Pipeline Routing Data Supplied to Utility Contractors 
DETAIL A: TYPICAL BURIAL FOR PIPE RUN BENEATH GRAVEL STREET (BURIAL FOR NON-STREET PIPING

SIMILAR: SEE NOTE 2)

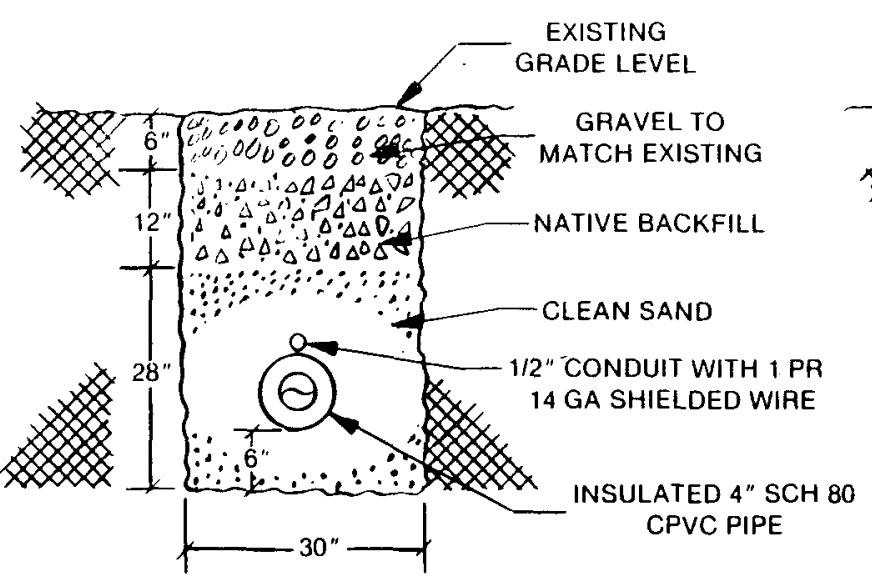

NOTES:

1. 4" SCH8OCPVC PIPE TO BE JOINED BY SOLVENT CEMENTING. 2" THICK URETHANE INSULATION HAVING PVC OR OTHER SUITABLE JACKET TO BE INSTALLED OVER PIPE. PIPE MAY BE FIELD INSULATED OR PREINSULATED. INSULATION OF JOINTS NOT REQUIRED

2. ALL BACKFILL AND OVERFILL MATERIALS TO BE WETTED AND COMPACTED IN 6" LAYERS. NATIVE BACKFILL OR TOP SOIL, AS APPROPRIATE, ACCEPTABLE IN PLACE OF GRAVEL WHEN NOT DITCHING THROUGH GRAVELLED OR PAVED STREETS.

3. APPROX. 12" CALICHE FILL TO BE USED IN PLACE OF CONCRETE AND 6" SAND WHEN CUTTING AND PATCHING PAVED STREETS NOT HAVING CONCRETE BASE.

4. EXPANSION LOOPS WITH $10 \mathrm{FT}$. EXPANSION LEGS REQUIRED AT EVERY $200 \mathrm{FT}$. OF STRAIGHT RUN PIPE.

5. ABOVE GRADE MARKER DENOTING PIPELINE LOCATION REQUIRED AT APPROXIMATELY $200 \mathrm{FT}$. INTERVALS AND AT ALL EXPANSION LOOP LOCATIONS

6. DRAWING DIMENSIONS MAY VARY ACCORDING TO SITE CONDITIONS OR IF REQUIRED TO BYPASS EXISTING UTILITY LINES. CONTRACTOR TO STUDY EXISTING UTILITY LOCATIONS AND PROCEED CAREFULLY SO TO PREVENT DAMAGE AND LOSS OF SERVICE OF EXISTING UTILITY LINES. ANY INTER. RUPTION OF SERVICE TO BE REPAIRED BY CONTRACTOR IMMEDIATELY AT NO ADDITIONAL COST TO THE OWNER
DETAIL B: TYPICAL BURIAL FOR PIPE RUN BENEATH CONCRETE-BASED SIMILAR; SEE NOTE 3

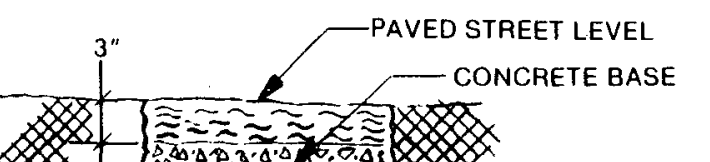
(INSTALLATION FOR PIPING RUN BENEATH HIGHWAY SIMILARI

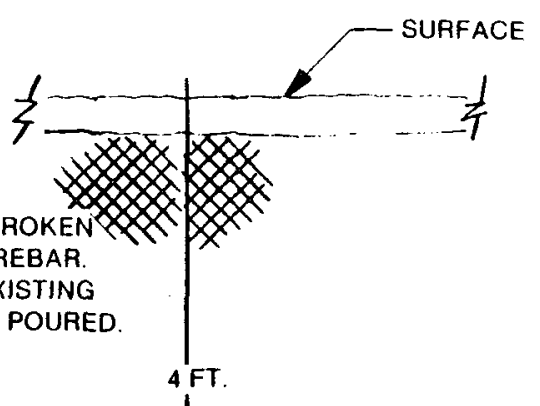

12" DIA CONCRETE CULVERT PLACED IN BORING

1/2" CONDUIT: SEE DETAIL A FIGURE 1 FOR DETAILS.

EXISTING CONCRETE BROKEN

NEW REBAR TIED TO EXISTING 28" 6 WHEN PATCH CONCRETE POURED.

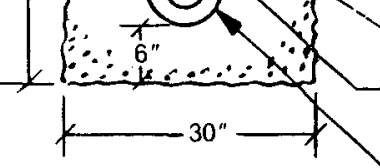
1/2" CONDUIT: INSULATED CPVC PIPE SEE

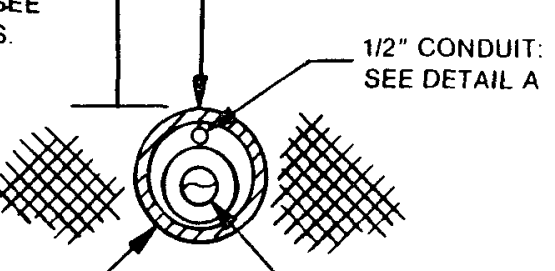

SAND PACKED AS NEEDED BETWEEN

INSULATED 4" SCH 80 CULVERT AND EXISTING CPVC PIPING

7. CONTRACTOR REQUIRED TO PROVIDE SURVEY AND AS-BUILT DRAWINGS SHOWING LOCATION, DEPTH, AND OTHER PERTINENT INFORMATION

8. REPAIR ALL SIDEWALKS AND OTHER CONCRETE CUTS

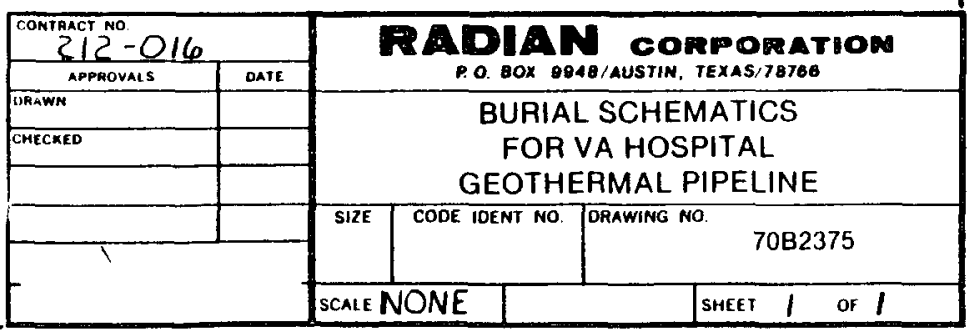


TABLE A-1. PIPELINE ESTIMATE SUMMARY

\begin{tabular}{|c|c|c|c|c|c|}
\hline Detail & Type of Excavation & $\begin{array}{l}\text { Approx. Lin. Ft. } \\
\text { of Insulated Pipe }\end{array}$ & $\$$ & $\begin{array}{l}\text { Approx. Lin. Ft. } \\
\text { of Uninsulated Pipe }{ }^{2,3}\end{array}$ & $\$$ \\
\hline \multirow[t]{2}{*}{ "A" } & $\begin{array}{l}\text { - Native soils or } \\
\text { grass }\end{array}$ & 1070 & & 40 & \\
\hline & $\begin{array}{l}\text { - Gravel roadway or } \\
\text { parking }\end{array}$ & 4120 & & 410 & \\
\hline \multirow[t]{2}{*}{ "B" } & $\begin{array}{l}\text { - Paved (asphalt) } \\
\text { street or parking }\end{array}$ & 520 & & $-0-$ & \\
\hline & $\begin{array}{l}\text { - Paved, concrete- } \\
\text { based street }\end{array}$ & 1020 & & 400 & \\
\hline \multirow[t]{4}{*}{ "C" } & $\begin{array}{l}\text { - Boring beneath } \\
\text { railway }\end{array}$ & 80 & & $-0-$ & \\
\hline & $\begin{array}{l}\text { - Boring beneath } \\
\text { highway }\end{array}$ & 100 & & 100 & \\
\hline & Subtotals & $6910^{\prime}$ & & $950^{\prime \prime}$ & \\
\hline & Total Est & & & & \\
\hline
\end{tabular}

${ }^{1}$ See attached sketches

"Includes allowance for expansion loop pipe, but does not include allowance for any fittings or valves. "Chemtrol" brand 4" CPVC butterfly valves to be instailed in approx. 300' intervals. These valves list at approx. \$200 each. Allow for these valves and associated flanges as well as for other ells and miscellaneous fittings.

${ }^{3}$ An uninsulated discharge line to be run in same trench as insulated supply line from the VAMC to drainage creek (see attached map). Accordingly, adjust Detail " $\mathrm{C}$ " sketch for an 18" dia. culvert to handle both lines beneath Highway 6. 